\title{
THE FCC'S PERSONAL ATTACK AND POLITICAL EDITORIAL RULES RECONSIDERED*
}

\author{
Steven J. Simmonst
}

Although much has been written about the Federal Communication Commission's fairness doctrine, the legal literature largely has ignored the Commission's articulation of that doctrine in its personal attack and political editorial rules. ${ }^{1}$ Under these rules, an individual or group that is attacked during a discussion of a controversial issue of public importance or a candidate who is not favored in a broadcast licensee's political editorial is provided an opportunity to respond over the air. In the following pages, an attempt will be made to examine these rules and the resulting case law in detail. This Article will begin with a brief look at the fairness doctrine and then proceed to trace the evolution of the personal attack and political editorial rules. Critical examinations of each of the rules in their current operational settings will lead to the conclusion that the personal attack rules should be repealed, but that, with some modifications, the political editorial rules, at least for the time being, should be retained.

\section{The Fairness Doctrine}

The FCC's personal attack and political editorial rules are considered subcategories of the Commission's fairness doctrine. Under that doctrine all television and radio licensees ${ }^{2}$ are re-

* This Article will appear subsequently as a chapter in a book by the author entitled The Fairsess Doctrine and THE Media, to be published by the University of California Press. Copyright $\odot 1977$ by Steven J. Simmons. All rights reserved.

† Assistant Professor, Program in Social Ecology, University of California, Irvine. B.A. 1968, Cornell University; J.D. 1972, Harvard University. Member, California Bar.

147 C.F.R. $\S \S 73.123$ (AM radio), .300 (FM radio), .598 (noncommercial educational FM radio), .679 (TV station), 76.209 ("origination cablecasting" over cable TV systems) (1976). The exceptions are articles focusing on first amendment issues raised by the rules. See, e.g., Comment, FCC's Formal Rules Concerning Personal Attacks and Political Editorials Contravene the First Amendment, 44 Notre Dame Law. 447 (1969).

${ }^{2}$ Like the personal attack and political editorial rules, the fairness doctrine also is applicable to cable television system operators who originate programming under their 
quired to do two things: First, they must devote a reasonable amount of their programming to controversial issues of public importance. Second, they must air contrasting sides of those issues-that is, be "fair."

Declining to issue specific rules with respect to these two general requirements, the FCC has not told licensees precisely how to determine what issue is raised in a broadcast, whether an issue is controversial or of public importance, what constitutes a reasonable opportunity to respond to viewpoints already aired, or what is a reasonable amount of programming on important, controversial issues. Rather, any guidelines that exist must be gleaned from agency and court decisions and occasional Commission policy statements. ${ }^{4}$

The key to understanding how the fairness doctrine is applied is the Commission's standard for judging licensees' actions under the doctrine: any fairness decision by a licensee will be upheld if it is reasonable and made in good faith. Both the Commission and the courts "have stressed the wide degree of discretion available under the fairness doctrine" and have stated "ad infinitum ad nauseam, that the key to the doctrine is no mystical formula but rather the exercise of reasonable standards by the licensee." The doctrine "cannot be applied with scientific and mathematical certainty." 6

Although the fairness doctrine has been severely criticized, ${ }^{7}$ the FCG does not take its requirements lightly. The Commission has stated that it regards "strict adherence to the fairness doctrine as the single most important requirement of operation in

exclusive control. 47 C.F.R. $\$ \$ 76.205, .209$ (1976). See generally Simmons, The Fairness Doctrine and Cable TV, 11 HaRv. J. Legrs. 629 (1974).

${ }^{3}$ Red Lion Broadcasting Co. v. FCC, 395 U.S. 367, 377 (1969) ("The broadcaster must give adequate coverage to public issues ... and coverage must be fair in that it accurately reflects the opposing views.").

4 The Commission has issued four key policy statements: 39 Fed. Reg. 32,288 (1974) ("Broadcast Procedure Manual, Revised Edition"); 39 Fed. Reg. 26,372 (1974) ("Fairness Doctrine and Public Interest Standards") [hereinafter cited as Fairness Report]; 29 Fed. Reg. 10,416 (1964) ("Applicability of the Fairness Doctrine in the Handling of Controversial Issues of Public Importance") [hereinafter cited as Fairness Primer]; Report of the Commission on Editorializing by Broadcast Licensees, 13 F.C.C. 1246 (1949) [hereinafter cited as Editorializing Report].

5 Democratic Nat'l Comm. v. FCC, 460 F.2d 891, 903 (D.C. Cir.), cert. denied, 409 U.S. 843 (1972).

${ }^{6} I d$. at 900 .

'See, e.g., Rosenfeld, The Jurisprudence of Fairness: Freedom Through Regulation in the Marketplace of Ideas, 44 FordhaM L. Rev. 877 (1976); Comment, Power in the Marketplace of Ideas: The Faimess Doctrine and the First Amendment, 52 Tex. L. Rev. 727 (1974); Comment, The FCC's Faimess Doctrine in Operation, 20 Buffalo L. Rev. 663 (1971). 
the public interest-the "sine qua non" for grant of a renewal of license." The importance the Commission attaches to the fairness doctrine is a function of the doctrine's major purpose: keeping the American people informed on vital issues essential to a healthy democracy. As the Commission stated in its 1949 Editorializing Report, it is the "right of the public to be informed ... which is the foundation stone of the American system of broadcasting." Inextricably linked with the goal of public information are the objectives of preventing powerful broadcasters from using a scarce resource-the airwaves-to control the data received by the American public and of providing general access for the views of various groups and individuals. ${ }^{10}$

Like the general fairness requirements, the personal attack and political editorial rules are geared, at least theoretically, to keeping the public informed of contrasting views on important public issues. Thus, a person who was attacked in a broadcast is not entitled to air time to respond unless the attack occurred during discussion of a controversial issue of public importance. ${ }^{11}$ When a response is presented, the public is given the opportunity to hear that a person involved in a public controversy may not be as the attacker depicted him. Similarly, the candidate who was not endorsed or who was specifically opposed in an editorial gets his chance to present a different view on how the public should rote. In providing these reply opportunities, the FCC not only attempts to keep the public informed, but also tries to prevent any licensee from using the power of his scarce airwave frequency to unduly influence the public and allows some access for those who have been harmed by a broadcast to respond to

\footnotetext{
${ }^{8}$ Committee for the Fair Broadcasting of Controversial Issues, 25 F.C.C.2d 283, $292(1970)$.

${ }^{9}$ Editorializing Report, supra note 4, at 1249. The Commission added: "It is axiomatic that one of the most vital questions of mass communication in a democracy is the development of an informed public opinion through the public dissemination of news and ideas concerning the vital public issues of the day." Id. More recently the Commission declared: "Full information is the theoretical underpinning of the broadcaster's two [fairness doctrine] duties." Handling of Public Issues Under the Fairness Doctrine and the Public Interest Standards of the Communications Act, Reconsideration of the Fairness Report, 58 F.C.C.2d 691, 693 (1976) [hereinafter cited as Reconsideration, Fairness Report].

1" See Red Lion Broadcasting Co. v. FCC, 395 U.S. 367, 390 (1969); Robert H. Scott, [1946] 3 RAD. REG. (P \& F) 259, 263-64; Editorializing Report, supra note 4, at 1248-50; Note, The Mayflower Doctrine Scuttled, 59 YALE L.J. 759 (1950). No particular individual, however, is entitled to access. Choice of spokesmen is made by the licensee.

${ }^{11}$ See text accompanying note 39 infra.
} 
it. $^{12}$ In the Commission's view, the personal attack and political editorial rules "serve to effectuate important aspects of the well established Fairness Doctrine ....."13

\section{The Development of The Rules}

\section{A. Pre-1967 Case Law}

Unlike the general fairness doctrine, the origins of which can be traced as far back as the Federal Radio Commission's decision in Great Lakes Broadcasting ${ }^{14}$ in 1929, specific FCC involvement with personal attacks and political editorials had a later start. In the first definitive Commission report on the fair-

${ }^{12}$ Although sharing many of the same objectives, the personal attack and personal editorial rules differ from the general fairness doctrine in several important ways. At the most obvious level, specific rules have been issued for personal attacks and political editorials, but not for the more general fairness doctrine situation. Unlike the general fairness situations, the licensee has no control over the reply speaker, must follow specific steps in notifying the reply speaker, has less control over the reply speaker's response format, and must pay a forfeiture if he is in violation of the rules. See text accompanying notes 14-81 infra. The licensee is also, of course, not obligated to air personal attacks in the first place, as he is to present controversial issues of public importance under the first part of the fairness doctrine.

1332 Fed. Reg. 10,303 (1967) ("Personal Attacks; Political Editorials"). In pursuit of its fairness objectives and in order to make the public benefits of the rules more accessible to the citizenry, the Commission provided a format for filing a complaint with the FCC in the wake of what a complainant considers to be a personal attack:

If you file a complaint with the Commission, a copy should be sent to the station. The complaint should contain specific information concerning the following matters: (1) The name of the station or network involved; (2) the words or statements broadcast; (3) the date and time the broadcast was made; (4) the basis for your view that the words broadcast constitute an attack upon the honesty, character, integrity, or like personal qualities of you or your group; (5) the basis for your view that the personal attack was broadcast during the presentation of views on a controversial issue of public importance; (6) the basis for your view that the matter discussed was a controversial issue of public importance, either nationally or in the station's local area, at the time of the broadcast; and (7) whether the station within 1 week of the alleged attack; (i) Notified you or your group of the broadcast; (ii) transmitted a script, tape, or accurate summary of the broadcast if a script or tape was not available; and (iii) offered a reasonable opportunity to respond over the station's facilities.

39 Fed. Reg. 32,290 (1974).

143 F.R.C. 33 (1929). For a history of the early development of the fairness doctrine, see Simmons, Fairness Doctrine: The Early History, 29 FED. CoM. B.J. 207 (1976). Although early, published Federal Radio Commission (FRC) or FCC cases focusing on personal attacks or political editorials are scarce, in at least one case a radio broadcaster's license was not renewed partially because of attacks made on judges, religious groups, a labor organization, and the Board of Health. Trinity Methodist Church, South v. FRC, 62 F.2d 850 (D.C. Cir.), cert. denied, 284 U.S. 685 (1932), 288 U.S. 599 (1933). In Mayflower Broadcasting Corp., 8 F.C.C. 333, 339-40 (1941), the FCC chastised a licensee for airing editorials in favor of political candidates and seemingly ordered licensees not to editorialize or advocate their personal views. The latter policy was reversed in the Editorializing Report, supra note 4, at 1252-53. 
ness doctrine, issued in 1949, the FCC stated: "[E]lementary considerations of fairness may dictate that time be allocated to a person or group which has been specifically attacked over the station, where otherwise no such obligation would exist." 15

The personal attack and political editorial case law, however, did not begin to evolve seriously until the early 1960's. In Clayton $W$. Mapoles,${ }^{16}$ a group of state and county officials from Florida complained that Mr. Mapoles, licensee of radio station WEBY, had used the station to attack them personally. They alleged that station broadcasts had accused them of political tricks, dictatorial tactics, utilizing their offices for personal gain, and otherwise had denigrated their personal character and integrity. Mapoles, they charged, was doing all this primarily to promote his own candidacy for the state senate.

The Commission, after a series of on-the-spot interviews, found that the licensee indeed had attacked the petitioners. It concluded: "Where, as here, the attacks are of a highly personal nature which impugn the character and honesty of named individuals, the licensee has an affirmative duty to take all appropriate steps to see to it that the persons attacked are afforded the fullest opportunity to respond." ${ }^{17}$ Finding, however, that Mapoles had offered the attacked individuals, in on-the-air announcements, an opportunity to respond over the station's facilities and had not used the station to promote his own candidacy for office, the Commission denied the petition for nonrenewal of Mapoles' license.

In a concurring opinion, FCC Chairman Newton Minow further delineated the kinds of "appropriate steps" that should be taken by licensees when personal attacks occur. "In many, if not most, cases," on-the-air statements offering response time to those personally attacked may not be enough. Rather, licensees may have to notify those to be attacked in advance of the broadcast, provide them with tapes or a verbatim text of the broadcast, or both. ${ }^{18}$

In Billings Broadcasting Co., ${ }^{19}$ decided the same year as Mapoles, the General Manager of the National Rural Electric Cooperative Association complained that a Montana radio sta-

\footnotetext{
${ }^{15}$ Editorializing Report, supra note 4, at 1252.

${ }^{16}$ [1962] 23 RAD. Reg. (P \& F) 586.

${ }^{17}$ Id. at 591 .

${ }^{18} I d$. at 593 (concurring statement of Chairman Minow).

${ }^{19}$ [1962] 23 RAD. REG. (P \& F) 951 (1962).
} 
tion had broadcast at least twenty editorials vilifying him in connection with the Association's position favoring the creation of Public Utility Districts in the state. He maintained that the station's offer allowing him to respond in an interview format was unfair and untimely because he had just arrived in town and could not prepare adequately. Although the Commission neither denied renewal of the license nor mandated absolutely the prior notice requirement advocated by Chairman Minow in Mapoles, it did state:

[W] here, as here, a station's editorials attack an individual by name, the "fairness doctrine" requires that a copy of the specific editorial or editorials shall be communicated to the person attacked either prior to or at the time of the broadcast of such editorials so that a reasonable opportunity is afforded that person to reply. ${ }^{20}$

In failing to supply copies of the protested editorials, the Montana station had violated fairness doctrine requirements.

The broadcasts in Mapoles and Billings involved attacks on officials already elected or appointed to office. Times-Mirror Broadcasting Co., ${ }^{21}$ on the other hand, focused on candidates seeking office. Two television commentators on KTTV in Los Angeles had made statements about the candidates and issues in the 1962 California gubernatorial campaign. In over twenty different broadcasts they had spoken either against incumbent Governor Brown and the Democratic Party or in favor of challenger Richard Nixon and the Republicans. Among their broadcasts were attacks on Brown such as one claiming "he is one of the greatest ignoramuses on Communism that ever lived or he is soft on it." 22 Their remarks apparently did not have much effect on the campaign's outcome; the former Vice President lost in his home state-ironically, he placed much of the blame on an alleged media bias against him. ${ }^{23}$ The commentators' statements did have significance, however, in the development of evolving personal attack and political editorial case law.

In response to a complaint from the Democrats, the Commission telegrammed KTTV that the station's two broadcasts

21" Id. at 953 .

21 [1962] 24 RAd. REg. (P \& F) 404.

2224 RAd. REg. at 411.

${ }^{23}$ N.Y. Times, Nov. 8, 1962, at 1, col. 7 . 
devoted to viewpoints opposed to those previously presented by the commentators did not adequately fulfill fairness doctrine requirements. KTTV's actions had violated "the right of the public to a fair presentation of views." 24 The Commission further asserted that if a station permits any person other than a candidate to attack one candidate or support another by direct or indirect identification, the station must "send a transcript of the pertinent continuity on each such program to the appropriate candidate immediately and should offer a comparable opportunity for an appropriate spokesman to answer the broadcast." 25 Responding to KTTV's objection that requiring such procedures might deter stations from covering election-period issues, the Commission sent a followup telegram a week later that exempted newscasts and news interviews, as well as discussion programs where contrasting spokesmen aired their views, from the personal attack notification procedures. ${ }^{26}$

Licensees were reminded of their personal attack responsibilities in a 1963 public notice ${ }^{27}$ that summarized the three decisions just discussed. The notice stated that a licensee should send the text of the pertinent continuity to the attacked party and include a "specific offer" to use his broadcast facilities for response. ${ }^{28}$ The 1964 Faimess Primer $^{29}$ also contained a section devoted to the "Personal Attack Principle"30 that similarly digested the pertinent FCC decisions. It also cited the Commission's response to an inquiry letter sent in 1963 stating that, even if the attack is made by a party unconnected with the station, a station must follow personal attack procedures and that if no tape or transcript is available, a licensee must send the most accurate summary possible to the party affected. ${ }^{31}$

In a Primer footnote, the FCC made four major points: the personal attack procedure is applicable only when statements are

${ }^{24} 24$ RAD. REG. at 408.

${ }^{25} I d$. No fine was imposed. The FCC apparently was satisfied with KTTV's promise to follow the Commission's mandate between the telegram date and the election.

${ }^{26} I d$. at 406 .

2728 Fed. Reg. 7,692 (1963) ('Stations' Responsibilities Under Fairness Doctrine as to Controversial Issue Programming").

${ }^{28}$ Id. In Springfield Television Broadcasting Corp. [1965] 4 Rad. Reg. 2d (P \& F) 681,685 , the Commission cited the public notice in declaring that a Springfield television station's mailing of editorial transcripts to all persons attacked did not fulfill its fairness obligations, because a specific response offer was not transmitted.

${ }^{29}$ Fairness Primer, supra note 4.

3"Id. 10,420-21.

${ }^{31}$ Id. (citing letter of September 18, 1963 to Douglas A. Anello). 
made "in connection with a controversial issue of public importance"; it is concerned only with attacks on a person's or group's "integrity, character, or honesty or like personal qualities"; it is not applicable to mere references to people or groups or mere disagreement about views on an issue; and it is not relevant to attacks on foreign leaders. ${ }^{32}$

During the same period that the FCC became active in the personal attack and political editorial area, legislative attention began to focus on the problem. The intense congressional concern about creating a viable remedial procedure for personal attacks, especially with respect to political candidates, was reflected in this 1963 statement addressed to FCC Chairman William Henry by Senator Pastore, Chairman of the Senate Subcommittee on Communications:

I think you ought to give the aggrieved party some immediate remedy. ... All you have to do is worry about setting up the mechanism for this person to bring his side to the public attention before it is too late.

I would hope the Commission would get into this immediately. ${ }^{33}$

Agreeing with Senator Pastore, Chairman Henry, at hearings before the House and Senate Subcommittees on Communications, indicated that the Commission was considering issuing specific rules with respect to personal attacks over the airwaves and recommended that legislation not be passed in this area. ${ }^{34}$ Nevertheless, it was almost three years before the FCC adopted a notice of proposed rulemaking to deal with the problem. ${ }^{35}$

${ }^{32}$ Id. 10,420 .

${ }^{33}$ Hearings on S. 251, S. 252, S. 1696, and H.R.J. Res. 247 Before the Subcomm. on Communications of the Senate Comm. on Commerce, 88th Cong., 1st Sess. 68 (1963). Pastore continued:

[A] small individual, what right of redress does he have? Take a person running for a school committee in the city of Providence. There is no remuneration for that position. And a local broadcasting station takes it upon itself, in a very spirited campaign for the school committee, which to the mothers of that community is just as important as the Presidency of the United States for the moment-the broadcaster comes along and endorses one candidate against the other. What protection does that little fellow have, unless you have something Id. 67-68.

in the law that gives him protection?

${ }^{34}$ Id. 97-98; Hearings on Broadcast Editorializing Practices Before the Subcomm. on Communications and Power of the House Comm. on Interstate and Foreign Commerce, 88th Cong., lst Sess., 89, 90 (1963) [hereinafter cited as Hearings on Broadcast Editorializing Practices].

3531 Fed. Reg. 5,710 (1966) ("Personal Attacks; Political Editorials, Notice of Proposed Rulemaking"). 


\section{B. The 1967 Rules and Amendments}

The Commission finally issued specific rules on July 10 , $1967 .{ }^{36}$ The two primary reasons advanced for embodying personal attack and political editorial procedures in rule form was to make licensing procedures more precise and clear and to provide a basis for imposing sanctions in the event of noncompliance. ${ }^{37}$ The rules are stated in three paragraphs:

Personal attacks; political editorials.

(a) When, during the presentation of views on a controversial issue of public importance, an attack is made upon the honesty, character, integrity or like personal qualities of an identified person or group, the licensee shall, within a reasonable time and in no event later than 1 week after the attack, transmit to the person or group attacked (1) notification of the date, time and identification of the broadcast; (2) a script or tape (or an accurate summary if a script or tape is not available) of the attack; and (3) an offer of a reasonable opportunity to respond over the licensee's facilities.

(b) The provisions of paragraph (a) of this section shall be inapplicable to attacks on foreign groups or foreign public figures or where personal attacks are made by legally qualified candidates, their authorized spokesmen, or those associated with them in the campaign, on other such candidates, their authorized spokesman, or persons associated with the candidates in the campaign.

NOTE: In a specific factual situation, the fairness doctrine may be applicable in this general area of political broadcasts. See, section 315 (a) of the Act (47 U.S.C. 315(a)); public notice: Applicability of the Fairness Doctrine in the Handling of Controversial Issues of Public Importance. 29 Fed. Reg. 10415.

(c) Where a licensee, in an editorial, (i) endorses or

${ }^{36} 32$ Fed. Reg. 10,305-06 (1967) (codified at 47 C.F.R. $\$ \S 73.123, .300, .598, .679$ (1976)).

37 Id. 10,303. The Commission stated that it would be able to impose forfeitures under 47 U.S.C. $\S 503$ (b) (1970) for willful or repeated violations. 32 Fed. Reg. 10,303 (1967). In testimony before the House Subcommittee on Communications in 1963, Chairman Henry had stated that rules also would make available cease and desist orders under $\$ 312(\mathrm{~b})$ and (c) and revocation under $\$ 312(\mathrm{a})(4)$. He suggested that it might also be appropriate to require licensees to retain records of efforts to air opposing views. Hearings on Broadcast Editorializing Practices, supra note 34, at 89-90. 
(ii) opposes a legally qualified candidate or candidates, the licensee shall, within 24 hours after the editorial, transmit to respectively (i) the other qualified candidate or candidates for the same office or (ii) the candidate opposed in the editorial (1) notification of the date and the time of the editorial; (2) a script or tape of the editorial; and (3) an offer of a reasonable opportunity for a candidate or a spokesman of the candidate to respond over the licensee's facilities: Provided, however, that where such editorials are broadcast within 72 hours prior to the day of the election, the licensee shall comply with the provisions of this subsection sufficiently far in advance of the broadcast to enable the candidate or candidates to have a reasonable opportunity to prepare a response and to present it in a timely fashion. ${ }^{38}$

In the text accompanying the announcement of the new rules, the Commission emphasized that the personal attack principle is part and parcel of the fairness doctrine and that the attack rules are applicable only when an attack occurs in the context of the discussion of a controversial issue of public importance. ${ }^{39}$ After brusquely rejecting arguments that the rules violate broadcasters' first amendment rights, ${ }^{40}$ the Commission stated that a licensee is responsible for what is broadcast over his facilities and must obey the personal attack rules even if the attack is made on a network show. ${ }^{41}$ The Commission tempered its warning, however, by noting that the rule would not be used to sanction those who seek to comply with it in good faith. ${ }^{42}$ It also stressed that personal attacks and political editorials were in no way prohibited; if such attacks or editorials were presented,

${ }^{38} 47$ C.F.R. $\$ \$ 73.123, .300, .598, .679$ (1976).

3932 Fed. Reg. 10,303-04 (1967). The Commission also said: " [T] of an informed public opinion through the public dissemination of news and ideas concerning the vital public issues of the day is the keystone of the Fairness Doctrine." " Id. 10,303 (quoting Editorializing Report, supra note 4, at 1249). The Commission stressed that private disputes involving personal attacks were not subject to the rules. $I d$. 10,304 .

${ }^{40} I d .10,303$.

${ }^{41}$ Id. 10,304 .

${ }^{42}$ Id. The Commission said that sanctions would be applied only when the licensee does not comply and "there can be no reasonable doubt under the facts that a personal attack has taken place (e.g., a statement in a controversial issue broadcast that a public official or other person is an embezzler or a Communist)." Id. Licensees were also advised promptly to consult the Commission in appropriate cases. Id. n.6. The Commission left the definition of "reasonable opportunity" to respond up to the licensee's reasonable, good faith judgment. Id. 10,305. 
however, the notification and reply opportunity requirements must be met. ${ }^{43}$ The Commission concluded its remarks by pointing out that campaign attacks by candidates and their spokesmen against other candidates had been excluded because they usually fall within the equal time bailiwick ${ }^{44}$ and, in offering a reply to a licensee political editorial, the licensee could air a candidate's spokesman instead of the candidate in order to avoid equal time obligations. ${ }^{45}$

Some of the procedures outlined in the new rules went further than the previous case law. For example, the new rules provided more specific time limits for notification and transmittal of the date and time of the broadcast and a more specific description of the proper form for an attack text reproduction. ${ }^{46}$ The Commission also expanded the scope of the personal attack principle by failing to exempt from personal attack rules, in apparent repudiation of one of its previous rulings, ${ }^{47}$ newscasts, news interviews, and discussion programs including opposing speakers. At the same time, the Commission loosened its requirements in some respects. Although earlier cases had indicated that notification of an attacked party should occur prior to or at the time of the broadcast containing the attack, ${ }^{48}$ the Commission did not require such advance or simultaneous notification in the rules. ${ }^{49}$

The news exemptions were reinstituted by two amendments to the rules that came within a year of the rules' promulgation.

${ }^{43}$ Id. $10,303$.

${ }^{44}$ Id. 10,305; see 47 U.S.C. $\$ 315$ (Supp. V 1975).

4532 Fed. Reg. 10,305 (1967). The Commission stated that, except in extraordinary circumstances, the candidate's spokesman should be chosen by the candidate. Id. n.9. The FCC made two other significant points. First, it reaffirmed its ruling in John $\mathrm{H}$. Norris, 1 F.C.C.2d 1587 (1965), aff'd sub nom. Red Lion Broadcasting Co. v. FCC, 395 U.S. 367 (1969), that the attacked party had to be given air time even if he could not pay for it. Second, the Commission noted that if a licensee decides that no personal attack has occurred, but thinks that there may be some dispute over this conclusion, he should keep a record of the broadcast for a reasonable time and make it available for public inspection. 32 Fed. Reg. 10,305 n.7 (1967).

46 "Foreign groups" were also added as an exempt category in addition to the "foreign leaders" category specified in the Fairness Primer, supra note 4, at 10,420 n.6.

47 Times-Mirror Broadcasting Co., [1962] 24 RAD. ReG. (P \& F) 404, 406.

${ }^{48}$ See Billings Broadcasting Co., [1962] 23 RAD. REG. (P \& F) 951, 953; Clayton W. Mapoles, [1962] 23 RAD. REG. (P \& F) 586, 593 (concurring statement of Chairman Minow).

49 The Commission did suggest that the one-week time limit "does not mean that such a copy should not be sent earlier or indeed, before the attack occurs, particularly where time is of the essence." 32 Fed. Reg. 10,305 (1967). Such earlier notification, however, was not required in the text of the rules. 
Less than a month after the rules were issued, the FCC exempted bona fide newscasts and on-the-spot coverage of bona fide news events from personal attack requirements ${ }^{50}$ on the grounds that requiring personal attack procedures for such programming might be impractical and impede the news functions of licensees. Standard journalistic practices were thought adequate to assure the broadcast of both sides of newsworthy personal attacks; in any case, the general fairness doctrine provided an ultimate safeguard. ${ }^{51}$ The same considerations also led the Commission later to exempt bona fide news interviews and news commentary or analysis contained in any newscast, news interview, or on-the-spot news coverage after CBS charged that the personal attack procedures inhibited journalism in these areas. ${ }^{52}$ The FCC added that it generally had not been faced with personal attack problems in the news categories being exempted and that it was simply tracking the exemptions Congress had made to the equal time requirements. ${ }^{53}$ It reminded licen-

50 32 Fed. Reg. I1,531 (1967) ("Procedures in Event of Personal Attack or Where Station Editorializes as to Political Candidates").

${ }^{51}$ Id. The Commission also noted that personal attacks occurring during on-thespot news coverage would be rare. $I d$.

5233 Fed. Reg. 5,362 (1968) (codified at 47 C.F.R. $\S \S 73.123(b), .300(b), .598(b)$, $.679(\mathrm{~b})(1976))$ :

(b) The provisions of paragraph (a) of this section shall not be applicable (1) to attacks on foreign groups or foreign public figures; (2) to personal attacks which are made by legally qualified candidates, their authorized spokesmen, or those associated with them in the campaign, on other such candidates, their authorized spokesmen, or persons associated with the candidates in the campaign; and (3) to bona fide newscasts, bona fide news interviews, and onthe-spot coverage of a bona fide news event (including commentary or analysis contained in the foregoing programs, but the provisions of paragraph (a) of this section shall be applicable to editorials of the licensee).

NOTE: The fairness doctrine is applicable to situations coming within (iii), above, and, in a specific factual situation, may be applicable in the general area of political broadcasts (ii), above. See, section 315(a) of the Act, 47 U.S.C. 315(a); Public Notice: Applicability of the Fairness Doctrine in the Handling of Controversial Issues of Public Importance, 29 F.R. 10415. The categories listed in (iii) are the same as those specified in section 315(a) of the Act.

${ }^{53} 33$ Fed. Reg. 5,362 (1968). The Commission refused to exempt licensee editorials, noting that there had been instances of failure to comply with the personal attack rules in the context of such editorials and news documentaries. The Commission distinguished its decision from the equal time news documentary exemption, which applies to incidental appearances by candidates. Id. 5,363; see 47 U.S.C. $315(a)(3)$ (1970). The Commission stressed that the fairness doctrine obligation to present contrasting views of controversial public issues, including relevant personal attacks, still applied to the exempt news programs. 33 Fed. Reg. 5,363 (1968). The Commission also buried in a footnote a significant exception to the personal attack rules: if the person attacked was given a fair opportunity to respond, at the time of an initial attack, to the substance of a later attack, compliance with the rules has been achieved. Id. 5,362 n.1. 
sees, however, that the general fairness doctrine still applied to the exempt categories. ${ }^{54}$

As with the fairness doctrine generally, the personal attack and political editorial rules on their face are applicable to both commercial and noncommercial broadcast stations and to origination cablecasting under the control of cable system operators. $^{55}$ The political editorial rules, however, do not have any real relevance for noncommercial stations because Congress has forbidden such broadcasters from editorializing or endorsing particular candidates for political office. ${ }^{56}$

\section{Emerging Guideposts in Post-1967 Decisions}

The most important post-1967 development involving the personal attack and political editorial rules-and indeed the fairness doctrine itself-was the Supreme Court's decision in Red Lion Broadcasting Co. 2 . FCC, ${ }^{57}$ which held the rules and the underlying fairness doctrine to be both statutorily authorized and constitutional. Aside from indicating that, as in general fairness doctrine cases, a licensee may not insist on payment from an attacked party for reply time, however, the case did not shed much light on how the rules were to be implemented.

A string of FCC decisions beginning in the late 1960's do

5433 Fed. Reg. 5,363. If a personal attack occurs in an exempt news program during discussion of a controversial public issue, the licensee may present "the contrasting viewpoint on the attack issue" itself under the general fairness doctrine. Id. If the licensee has not and does not plan to do so, it is not appropriate for the licensee to make over-the-air offers of time to respond. "There is a clear and appropriate spokesman to present the other side of the attack issue-the person or group attacked." Id. The licensee should notify and allow "the person or group attacked a reasonable opportunity to respond." Id. In the latter situation, however, the precise time limitation and notification requirements of the personal attack rules do not apply. See Rev. Paul E. Driscoll, 40 F.C.C.2d 448 (1973) (fairness doctrine applicable to alleged attack on Rev. Driscoll and Catholic Church made during exempt bona fide news interview).

5547 C.F.R. \$§ 73.123(a)(b) (AM radio), .300(a)(b) (FM radio), .598(a)(b) (noncommercial educational FM radio), .679(a)(b) (TV stations), 76.209(b)(c) (origination cablecasting over cable TV systems) (1976).

56 47 U.S.C. \& 399(a) (Supp. V 1975).

s7 395 U.S. 367 (1969); see text accompanying notes 134-35 infra. For discussions of Red Lion, see F. Friendly, The Good Guys, The Bad GuYs, aNd THE First AMENDMENT, 32-77 (1976); Blake, Red Lion Broadcasting Co. \%. FCC: Fairness and the Emperor's New Clothes, 23 FED. Com. B.J. 75 (1969); Firestein, Red Lion and the Fairness Doctrine: Regulation of Broadcasting "in the Public Interest," 11 ARIz. L. Rev. 807 (1969); 15 S.D. L. REv. 172 (1970). One recent interesting allegation with first amendment implications is the charge that the complainant in Red Lion was actually working with the Democratic Party as part of a secret national campaign on behalf of the Kennedy Administration to utilize the personal attack rules and general fairness doctrine to silence or hamper right wing commentators. See F. FRIENDLY, supra, at 33-42. 
provide some guidance. The FCC stated repeatedly that passing references $t^{58}$ or mere disagreement with ${ }^{59}$ individuals or groups do not constitute attacks. It indicated that an attack can be made even when an individual is not named specifically, as long as he is sufficiently identified. ${ }^{60}$ The Commission reaffirmed the attack rules' exemption of newscasts, ${ }^{61}$ bona fide news interviews, ${ }^{62}$ and attacks made on candidates by supporters of other candidates. ${ }^{63}$ It stressed that, because the purpose of the rules is to inform the public on "vital issues of the day" and not to settle private disputes, for the personal attack rules to apply the attack must occur during discussion of a controversial issue of public importance. ${ }^{64}$

${ }^{38}$ See, e.g., Herschel Kasten, 39 F.C.C.2d 566 (1973).

${ }^{59}$ See, e.g., Port of N.Y. Auth., 25 F.C.C.2d 417, 418 (1970); Miners Broadcasting Serv., Inc., 20 F.C.C.2d 1061, 1063 n.6 (1970).

${ }^{61}$ See Rev. Paul E. Driscoll, 40 F.C.C.2d 448 (1973). Driscoll can be read as implying that a person can be identified sufficiently for personal attack rule purposes without being specifically named because the Staff did not question complainant's assertion that the broadcast sufficiently identified him. The letter, however, did not directly comment on the identification issue because it found that the comments were made during a bona fide news interview. But see Diocese of Rockville Centre, 50 F.C.C.2d 330 (1973) (charges that the men in the Roman Catholic Church were led into it "merely by ambition" and were "hypocritical and immoral" did not identify sufficiently the alleged attack victims).

${ }^{61}$ Quechee Lakes Corp., 38 F.C.C.2d 1039 (1973) (accusation within news broadcasts that land development corporation used deceitful practices); Dorothy Healey, 24 F.C.C.2d 487 (1970), aff'd sub nom. Healey v. FCC, 460 F.2d 917 (D.C. Cir. 1972) (broadcaster calling individual Marxist, Communist, and atheist in commentary part of news broadcast). But of. Walker and Salveter, [1975] 32 RAD. REg. 2d (P \& F) 839, 844 (the "Commission has not exempted the labeled station or network editorial, even if occurring in one of these exempt categories").

${ }^{62}$ Rev. Paul E. Driscoll, 40 F.C.C.2d 448 (1973) (alleged attack made during bona fide news interview).

${ }_{63}$ Thomas R. Asher, 38 F.C.C.2d 300 (1972) (accusation that President Nixon's supporters distorted Senator McGovern's welfare position and personally attacked him in campaign advertisements). Under the political editorial and the personal attack rules, the Commission looks to the definition of "legally qualified candidate" as interpreted under the equal time requirements of $\S 315$ of the Communications Act of 1934, 47 U.S.C. $\$ 315$ (1970 \& Supp. V 1975). See Arthur W. Arundel, 14 F.C.C.2d 199 (1968) (editorial endorsement of Robert Kennedy for President required notification and opportunity to respond for other legally qualified candidates, but not for Senator Humphrey, who had not yet announced his candidacy); Senator Eugene J. McCarthy, 11 F.C.C.2d 5 I 1 (1968) (since personal attack rules are inapplicable to a legally qualified candidate's attack on another such candidate, alleged personal attack made by President Johnson must be based on assumption that Johnson was not yet a legally qualified candidate). An attack made by a legally qualified candidate upon a person not a candidate or associated with a candidate is subject to the personal attack requirements, despite the fact that the licensee cannot censor comments by candidates under $\$ 315$. Capitol Cities Broadcasting, 13 F.C.C.2d 869 (1968) (candidate identified noncandidates as having been indicted for sedition, referred to their allegedly "subversive activities," and quoted excerpts from grand jury report).

${ }_{64}$ National Ass'n of Gov't Employees, 41 F.C.C.2d 965 (1973). 
The Commission also emphasized the importance of the notification obligations. If there is any question whether statements made in a broadcast comprise a personal attack within the meaning of the rules, the licensee must retain a tape, script, or contemporaneously made summary of the remarks. ${ }^{65}$ The FCC further declared that licensee inquiries to the Commission seeking advice on whether an attack has occurred should be made promptly, and that, despite any uncertainty, the potentially attacked party should be notified within the prescribed seven-day period. ${ }^{66}$

FCC decisions further refined the meaning of "a reasonable opportunity to respond" in the personal attack context. As in the area of the general fairness doctrine, "what constitutes a reasonable opportunity to respond" is largely a "matter . . . for the good faith, reasonable judgment of the licensee." 67 This "good faith, reasonable judgment" must be made by the licensee with regard to both the placement of the response program and the amount of time to be afforded for the reply. ${ }^{68}$ The Commission, however, tightened these loose-fitting fairness doctrine requirements by forbidding a licensee to insist that a reply to a personal attack be made as part of roundtable or panel discussion, where a moderator and questions or debate are involved. ${ }^{69}$ Instead, the

${ }^{65}$ Dr. Morris Crothers, 32 F.C.C.2d 864 (1971). The Commission stated that although the licensee

had no obligation to tape such remarks, under the circumstances of this case

[it] should have retained a tape if one was made or, if a recording was not made, retained at least an accurate and contemporaneously made summary or transcript of the remarks, instead of relying on "recollections" of [its] moderator....

Id. at 865. As do many of the personal attack cases, Crothers involved a phone-in talk show.

${ }^{66}$ Station WGCB, 41 F.C.C.2d 340, 342 (1973) ("A three months delay in seeking Commission advice obviously precludes any finding of a reasonable attempt of compliance with the rule.").

${ }^{67}$ John Birch Soc'y, 11 F.C.C.2d 790, 791 (1968).

${ }^{68}$ Id. at 791. The Commission added that the licensee should consider "the time devoted to the attack and other pertinent considerations," and, in the "case of an attack in a program which is one of a series," a reasonable judgment may be demonstrated by "inclusion of the response during a portion of the time period regularly allotted to the series ... if otherwise fair to the person attacked . . . and if effectuated by the licensee and not simply delegated to someone associated with the program series." Id. See Station WGCB, 41 F.C.C.2d 340, 342 (1973) (reasonable opportunity is "initially to be worked out by the licensee and the party"); John M. Slack, 26 F.C.C.2d 11 (1970) (three minutes reply time on 6 and 11 p.m. news is reasonable); Dean C. Steele, 18 F.C.C.2d 661 (1969) (offering an attacked party precisely equal time is reasonable).

${ }^{69}$ John Birch Soc'y, 11 F.C.C.2d 790, 791-92 (1968). Under the general fairness doctrine, a licensee may determine the format in which a spokesman will present his 
attacked party must be afforded a more direct opportunity to reply, although the licensee can insist that the reply be reasonably responsive to the attack. ${ }^{70}$ The attacked party's reply may not be prefaced or followed by repetition or justification of the original attack, ${ }^{71}$ nor may the licensee determine the reply spokesman-as he may in the ordinary fairness situationbecause the person who responds ordinarily should be the person who was attacked or his designated spokesman. ${ }^{72}$ If the attacked party is on the line of a radio phone-in show while the attack takes place and has an immediate opportunity to respond, however, the licensee, without more, has complied with the personal attack rules. ${ }^{73}$

"A reasonable opportunity to respond" has undergone similar case law definition in the political editorial context in the post- 1967 period. The FCC held that if a candidate's response to a station's endorsement of another candidate is preceded by repetition of the endorsement, the reply opportunity is not reasonable and the licensee will incur additional reply obligations unless the responding candidate either agrees to the repetition or is going to challenge the original endorsement by "specific mention thereof." 74 Moreover, the Commission tightened the parameters of what constitutes a reasonable opportunity to respond. Thus, total time ratios of approximately 4 to $1^{75}$ and 2.7 to $1^{76}$ (licensee editorial time to candidate reply time) were considered unreasonable, as were frequency of broadcast ratios of 4

opposing views. Fairness Report, supra note 4, at 26,378; Editorializing Report, supra note 4 , at $1251,1257-58$.

71' John Birch Soc'y, 11 F.C.C..2d 790, 792 (1968) (licensee's rejection of a general film about Robert Welch offered as a rebuttal to attacks on the John Birch Society upheld). A licensee's judgment on the responsiveness of a proposed reply to a personal attack may, of course, be deemed unreasonable. See Radio Albany, Inc., 40 F.C.C. 632, 634 (1965) (licensee's judgment that Rev. Martin Luther King, Jr.'s proposed reply to editorial attack was unresponsive to the attack found unreasonable).

7 Station WGCB, 41 F.C.C.2d 340 (1973).

72 See Radio Albany, Inc., 40 F.C.C. 632,633 (1965).

${ }^{73}$ Lew H. Cherry, 25 F.C.C.2d 887 (1970).

${ }^{74}$ Mario Procaccino, 20 F.C.C.2d 451 (1969).

${ }^{75}$ James Spurling, 30 F.C.C.2d 675 (1971) (unreasonable, in city council election, for licensee editorial to devote 25 lines to endorsement of two other candidates and opposition to complainant's candidacy, and allow only six lines for reply; 4 to 1 total time ratio assumption is based on 4 to 1 total line ratio).

${ }^{76}$ Bill Bishop, 30 F.C.C.2d 829 (1971) (unreasonable for licensee to air seven editorial endorsements of one candidate for mayor totalling 11 minutes, 24 seconds but allow opposing candidate's spokesman to reply in only two broadcasts totalling four minutes, 18 seconds). 
to $1^{77}$ and 7 to $2^{78}$ (number of licensee editorial broadcasts to candidate reply broadcasts). Although precisely equal time has not been required under the political editorial rules, ${ }^{79}$ greater equality is demanded than in the general fairness context. ${ }^{80}$ The Commission declared: "In many instances a comparable opportunity in time and scheduling will be clearly appropriate" in the political editorial and personal attack situations. ${ }^{81}$

\section{Problems in Implementation of the Personal Attack Rules}

The FCC's rulings in the personal attack area have left an inconsistent and confusing trail of precedent on the critical questions of what constitutes a personal attack, what constitutes a controversial issue of public importance and how closely the attack must follow or precede discussion of the issue in order to be "during the presentation" of that issue. The precedent has generated other problems as well.

\section{A. What Constitutes an Attack?}

The following are demonstrative pairings of Commission rulings on what constitutes a personal attack under the rules. ${ }^{82}$

(1) Claiming that' a County Board had " 'hoodwinked' a governmental agency" in part by using county vehicles for "taxi service" and had sold land in violation of the law, and accusing a

${ }^{77}$ George E. Cooley, 10 F.C.C.2d 969 (1967) (unreasonable for licensee to endorse candidate in 24 twenty-second editorials and offer candidate's opponent six twentysecond response broadcasts).

${ }^{78}$ Bill Bishop, 30 F.C.C.2d 829 (1971).

${ }^{79} 32$ Fed. Reg. 10,305 (1967). Moreover, the licensee may require appearance of a candidate's spokesman instead of the candidate himself to avoid equal time obligations. Id. "Barring extraordinary circumstances" the choice of said spokesman is up to the candidate. Id. n.9. The licensee should look to equal time case law to define a "legally qualified candidate" in the political editorial context. Arthur L. Arundel, 14 F.C.C.2d I99 (1968). Unlike the equal time situation, in which the licensee can wait until the opposing candidates contact him for equal opportunities, the licensee must notify other candidates of his political editorials on his own initiative. Text accompanying notes 38 \& 43 supra.

${ }^{80}$ Total time ratios of 5.6 to 1 have been held reasonable under the general fairness doctrine, National Broadcasting Co., 16 F.C.C.2d 956 (1969), and frequency ratios of " 4 or 5" to 1 similarly have been upheld, Wilderness Soc'y, 31 F.C.C.2d 729, 735 (1971) (concurring statement of Chairman Burch).

${ }^{81} 32$ Fed. Reg. 10,305 (1967).

82 The Commission has stressed that the truth or falsity of a statement is not determinative of whether there has been a personal attack and that the Commission makes no inquiry into the accuracy of the alleged attack. Lew H. Cherry, 25 F.C.C.2d 887,888 (1970). 
county commissioner of taking a "champagne flight" for personal gratification when only authorized to fly on government business, do not constitute personal attacks; ${ }^{83}$ but suggesting that the management of a local radio station may have dynamited the station transmitter to hoodwink the insurance company and fraudulently collect insurance proceeds, does. ${ }^{84}$

(2) Asserting that the Roman Catholic Church was illegally lobbying against abortion ${ }^{85}$ and that a state legislator was projecting a conflict of interest image because of his private dealings ${ }^{86}$ are not attacks; but implying that a political candidate might be receiving campaign contributions from crime figures, is. ${ }^{87}$

(3) Claiming that doctors and nurses in a hospital are "incompetent" is not an attack; ${ }^{88}$ but suggesting that a female newspaper reporter obtained good interviews because of the way she positioned her legs and that she should get a job in a massage parlor, is. ${ }^{89}$

(4) Calling a person an "extremist" and a "patriotic extremist" is not an attack; ${ }^{\text {" }}$ but asserting that an institute and its newsletter are "subversive," to the "Far Left," and run by a "Communist," is. 91

${ }^{83}$ Senator Florian W. Chmielewski, 41 F.C.C.2d 201 (1973). The Commission added:

Criticism of a public official's wisdom, judgment or actions is not necessarily an attack upon his "honesty, character, integrity or like personal qualities," and we have stated that we shall not impose penalties in this area if the licensee could have had a reasonable doubt whether such an attack had taken place, or indeed in any case which does not involve a flagrant, clear-cut violation.

Id. at 207.

${ }^{84}$ Richard S. Manne, 26 F.C.C.2d 583 (1970).

${ }^{85}$ Rev. Paul E. Driscoll, 40 F.C.C.2d 448 (1973). The Commission declared:

[I]t should be clear that not all charges of illegality present attacks on honesty, character or integrity. One may assert that a person or group has in fact acted in violation of that law although the person or group assumed that such action was in full accord with the law's provisions. In such case, the charge is one of "illegality", but it is the judgment of the person or group in interpreting the law which is questioned, not their honesty, character or integrity.

Id. at 450 .

${ }^{86}$ John J. Salchert, 48 F.C.C. $2 d 346$ (1974) (legislator chaired a legislative nursing home committee while working for several nursing homes).

${ }^{87}$ Francis X. Bellotti, 10 F.C.C.2d 328 (1967).

${ }^{8 s}$ Rome Hosp., 40 F.C.C.2d 452 (1973).

${ }^{89}$ The Charlotte Observer, 38 F.C.C.2d 522 (1972). The Commission rejected the station's assertions that the remarks were intended to be "humorous, . . . not malicious" and may only have demonstrated "questionable taste." Id. at $\mathbf{5 2 3 .}$

${ }^{90}$ Columbia Broadcasting Sys., Inc., [1971] 21 RAD. REg. 2d (P \& F) 497. The Commission added: "Mere mention of groups of persons, or even certain types of unfavorable references thereto, do not constitute personal attacks as defined by the Commission." Id. at 497.

${ }^{91}$ WIYN Radio, Inc., 35 F.C.C.2d 175 (1972). 
(5) Stating that a university is a "breeding ground for Arab revolutionaries and terrorists," a "Guerrilla U.," and a "pipeline to the Palestinian guerrilla movement" is not an attack; ${ }^{\mathbf{9 2}}$ but claiming that the John Birch Society engages in "physical abuse and violence" and "local terror campaigns against opposition figures,"93 and asserting that the United Church of Christ is "part of a conspiracy to cause prison unrest through illegal and violent means" and is financing "violent and/or subversive" groups, are. ${ }^{94}$

(6) Calling two United States Senators "liberals and socialists" is not an attack; ${ }^{95}$ but declaring that a university professor is a "Communist," is. ${ }^{96}$

(7) Declaring that a teacher federation was subjecting the public to "blackmail," demanding "blood money," and in effect that its members were "unscrupulous criminals" is not a personal attack $;{ }^{97}$ but calling a congressman a "coward" for not appearing on an interview show, is.98

Many of these decisions, analyzed individually, do not appear unreasonable. ${ }^{99}$ But, as Professor Benno Schmidt suggests,

${ }^{92}$ J. Allen Carr, 30 F.C.C.2d 894 (1971).

${ }^{93}$ John Birch Soc'y, 11 F.C.C.2d 790, 791 (1968).

${ }^{94}$ Station WGCB, 41 F.C.C.2d 340, 342 (1973).

95 Thomas O'Brien, 42 F.C.C.2d 1106 (1973). The Commission added: "Comments of this nature refer to political ideological beliefs and do not constitute character denunciation." Id. at 1107 . In light of the FCC's affording personal attack replies to those termed "Communist," this statement is astounding.

${ }^{96}$ Brandywine-Main Line Radio, Inc., 24 F.C.C.2d 18, 26 (1970), aff'd, 473 F.2d 16 (D.C. Cir. 1972), cert. denied, 412 U.S. 922 (1973); cf. William M. Kunstler, 11 F.C.C.2d 678 (1973) (characterizing a club as a Communist organization is an attack).

${ }^{97}$ Philadelphia Fed'n of Teachers, 48 F.C.C.2d 507, 510 (1974).

${ }^{98}$ Straus Communications, Inc., 51 F.C.C.2d 385 (1975), vacated and remanded, 530 F.2d 1001 (D.C. Cir. 1976). Commissioner Robinson, in dissent, made the following telling comments on Straus in light of Philadelphia Fed'n of Teachers:

No differences in the dictionary definition of the vituperative words used, and nothing in common sense can make these two cases consistent. I can find no principle that justifies them. It may be, of course, that these are among the species of cases for which principles do not really suffice, and that must consequently be decided according to the length of the Chancellor's foot. If a certain amount of arbitrariness is necessary to finish important business in realms where mere language will not carry us, so be it. But in such cases, it is the Chancellor's duty at least to try to keep his foot from changing size like Alice in Wonderland.

51 F.C.C.2d at 390 (Commissioner Robinson, dissenting) (footnote omitted).

${ }^{99}$ For examples of other comments held not to be personal attacks, see Thaddeus Kowalski, 42 F.C.C.2d 1110 (1973) (making "Pollack jokes"); John Cervase, 42 F.C.C.2d 613 (1973) (calling an individual a "political opportunist"); Dewey M. Duckett, Jr., 23 F.C.C.2d 872 (1970) (calling an individual a "spook").

Consistently with the general fairness doctrine, see text accompanying notes 4-6 supra, the FCC claims to use a "reasonableness" standard in assessing licensee determi- 
when rulings such as these "are read together, the decisions seem haphazard, and they hopelessly confuse any effort to figure out what general principles delineate the scope of the personal attack rules."100 The Commission often fails even to provide rationales for its findings that particular comments constitute personal attacks. ${ }^{101}$

To be sure, some generalizations can be made. The Commission does not seem to consider mere policy disagreements ${ }^{102}$ or charges of incompetence or bad judgment ${ }^{103}$ to be personal attacks. Allegations of criminal activity, ${ }^{104}$ moral turpitude, communist or subversive activity, or promotion of violence, on the other hand, generally are held to constitute such attacks. Nevertheless, as the above cases indicate, the pattern is extremely hard to follow and riddled with inconsistency. For ex-

nations of when personal attacks have been made. See, e.g., Senator Florian W. Chmielewski, 41 F.C.C.2d 201, 208 (1973) ("[T]he question . . . is not what our initial view might be . . . but rather whether the licensee could reasonably judge the allegations not to involve personal attacks."). This flexible view might seem to explain the Commission's inconsistent holdings outlined at text accompanying notes 83-98 supra. The question, however, then becomes: "What sorts of determinations will be found 'reasonable?'" The answers to that question are no more coherent and provide no more guidance than the answers to the original question: "What sorts of remarks will be found to constitute personal attacks?" In other words, the problem remains however the question is formulated.

${ }_{10 n}$ B. Schmidt, Jr., Freedom of the Press vs. Public Access 171 (1976).

${ }^{101}$ See, e.g., Francis X. Bellotti, 10 F.C.C.2d 328 (1967); note 87 supra \& accompanying text.

${ }_{102}$ The distinction between policy differences and charges of dishonesty, moral turpitude, or criminal conduct, however, may be extremely tenuous. See, e.g., Sidney Willens, 33 F.C.C.2d 304, 306 (1972) (A charge that judges handed out illegal sentences found not to be an attack, the Commission stating that there "is an important distinction ... between contending that a judge has exceeded his discretion in the legal sense ... and charging that he has decided a case because of improper or corrupt motives."); John B. Walsh, 31 F.C.C.2d 726 (1971) (A charge that county supervisors engaged in mental gymnastics and were inconsistent in providing free office space to senator and enacting a tax increase found not to be an attack.); Port of N.Y. Auth., 25 F.C.C.2d 417,418 (1970) (A charge that Port Authority Commissioners were secretive and developed port in a way "most profitable to them" found not to be an attack, the Commission noting that "strong disagreement, even vehemently expressed, does not constitute a personal attack, in the absence of an attack upon character or integrity."); notes 83, 85, 97 supra \& accompanying text.

${ }^{113}$ See, e.g., Herschel Kasten, [1973] 27 RAd. REg. 2d (P \& F) 93 (calling a person unqualified to be head of a college); Robert B. Choate, 29 F.C.C.2d 73 (1971) (charge that individual's conclusions about biology topics were childish and that he was not suited for any work not an attack).

${ }_{114}$ See, e.g., Joseph A. Gillis, 43 F.C.C.2d 584 (1973) (claims that a doctor is a convicted abortionist, had "paid off police officers" to continue his "abortion racket," and had gone to jail rather than describe his payoffs to the Grand Jury is an attack); Dr. John Gabler, 40 F.C.C.2d 579 (1973) (accusing doctor of unethical conduct in deaths of two boys and of having been convicted for the death of one boy is an attack). 
ample, in many cases, the line between charges of incompetence and bad judgment and those involving integrity or character seems very unclear and difficult to administer. Indeed, insofar as the purpose of the rules is to keep the public informed about important, controversial issues, it would seem that questions about certain individuals' competence and judgment often may be more important than other private, moral questions. Commission rulings, however, do not seem to be consistently sensitive to the purposes behind the rules.

\section{B. What Is a Controversial Issue of Public Importance?}

As earlier noted, ${ }^{105}$ an attack triggers the rules' obligations only if it occurs during discussion of a controversial issue of public importance. Therefore, the question of whether an issue raised is controversial and of public importance, so troublesome in the general fairness doctrine context, ${ }^{106}$ must be answered. The Commission usually has failed to provide any rationale for why a particular issue is considered to be controversial or of public importance. The factors of media coverage, official and community leader attention, and impact that were stressed in the 1974 Fairness Report, ${ }^{107}$ are generally ignored. Thus, the radio discussion of a national organization's alleged association with Communists and alleged infiltration of the Methodist Church were found to be "clearly . . . controversial issues of public importance" in WIYN Radio, Inc. ${ }^{108}$ Yet no evidence of controversy in the community or statements by officials or leaders indicating the issue's importance was offered by the Commission to support its "clear" conclusion. The same lack of analysis is evident in

111 See text accompanying notes 11,39 supra.

110 The FCC itself has stated, "One of the most difficult problems involved in the administration of the fairness doctrine is the determination of the specific issue or issues raised by a particular program." Fairness Report, supra note 4, at 26,376. The Commission has laid down a series of inconsistent decisions on what issue is raised in a broadcast and whether it is controversial and of public importance. See, e.g., Accuracy in Media, Inc., 40 F.C.C.2d 958 (1973), remanded with direction to vacate order and dismiss complaint sub nom. National Broadcasting Co. v. FCC, 516 F.2d 1101 (D.C. Cir. 1974), cert. denied sub nom. Accuracy in Media, Inc. v. National Broadcasting Co., 424 U.S. 910 (1976); National Broadcasting Co. v. FCC, 516 F.2d 1101, 1156 (1974) (Bazelon, C.J., dissenting); Simmons, Commercial Advertising and the Fairness Doctrine; The Nezu F.C.C. Policy in Perspective, 75 Colum. L. Rev. 1083, 1086-1100 (1975); Comment, The Regulation of Competing First Amendment Rights: A New Fairmess Doctrine Balance After CBS?, 122 U. PA. L. Rev. 1283, $1293-1304$ (1974).

${ }^{111}$ Fairness Report, supra note 4, at 26,376.

11835 F.C.C. 2 d 175, 180 (1972). 
other Commission conclusions on whether issues, such as the role of the radical right ${ }^{109}$ or whether the DuBois Clubs are being used by the Communist Party to subvert American youth, ${ }^{110}$ are controversial and of public importance. The Commission's rejection of some personal attack complaints because the complainants had not "furnished the Commission with any information to indicate that there was a public debate or controversy in the community ... so as to create a controversial issue of public importance,"111 is absurd in light of its totally unsupported conclusions in other cases.

As might be expected from the Commission's failure to supply supporting rationales, the FCC's decisions on whether issues are controversial and of public importance display a lack of consistency. For example, the Commission found that the dismissal of an individual doctor from a city hospital was a controversial issue of public importance, ${ }^{112}$ but an election between branches of two national labor unions involving 1,230 employees and affecting thousands of households was held not to involve such an issue. ${ }^{113}$ A station management's alleged dynamiting of its transmitter in violation of public interest responsibilities was a controversial issue of public importance, ${ }^{114}$ but a license renewal application, the success of which similarly determined whether the station could continue to broadcast, was not. ${ }^{115}$

\section{The "During the Presentation" Requirement}

A significant question that has received very little attention is how close in time the personal attack must be to the discussion of the controversial issue of public importance in order for the attack to have been made "during the presentation" of that issue. The few Commission and staff statements on this question indicate that the FCC is taking an overly expansive view of when an

${ }^{1119}$ John Birch Soc'y, 11 F.C.C.2d 790 (1968).

11" William M. Kunstler, 11 F.C.C.2d 678 (1968).

111 National Ass'n of Gov't Employees, 41 F.C.C.2d 965, 966-67 (1973).

112 Dr. John Gabler, 40 F.C.C.2d 579 (1973). The licensee apparently admitted, however, that the dismissal involved a controversial issue of public importance. Id. at 580 .

${ }_{113} / d$.

114 Richard S. Manne, 26 F.C.C.2d 583 (1970). The conclusion, typically, was reached without any supporting evidence or rationale.

115 Duane Lindstrom, 26 F.C.C.2d 373 (1970). Lindstrom was a general fairness doctrine case; newspaper articles submitted by complainant did "not demonstrate that the license renewal of one or more specific stations is a controversial issue of public importance." Id. at 375 n.4. 
attack is made during the presentation of an issue.

In Richard S. Manne, ${ }^{116}$ an accusation that a rival station had intentionally dynamited its transmitter was considered a personal attack made during discussion of a controversial public issue even though the Commission had not received the "specific language of the discussion during which the statement was made ...."117 That the station making the broadcast had engaged in a "continuing discussion" of the construction and operation of the rival station was considered sufficient to establish that the "during the presentation" requirement had been met.

Three years later, in Thomas O'Brien, ${ }^{118}$ this requirement was given a seemingly more restricted reading. Unnamed college professors were accused of treason in the first of a three-part program, and two were named in the second and third parts. The "during the presentation" requirement was met "even though the charge of treason and the naming of the professors took place in three different portions of the speech, since the three portions are so closely related as to constitute a continuing discussion of the same issue." 119 This result seems reasonable; all three parts dealt with the same topic and explicitly were presented by the broadcaster as interdependent segments.

Straus Communications, Inc. ${ }^{\mathbf{1 2 0}}$ is the most significant case dealing with this issue. The case involved a comment made by Bob Grant, the host of a phone-in show on radio station WMCA in New York City. On March 8, 1973, Grant began the phonein program by reviewing the news of the day, including the nationwide meat boycott then in progress. Shortly after announcing that Benjamin Rosenthal, a local congressman and leader in the boycott, would soon be interviewed over the phone, Grant learned that Rosenthal had refused to be interviewed. Grant then told the audience of Rosenthal's refusal, suggested it might have resulted from past differences between the congressman and himself, and emphasized that he nonetheless agreed with the congressman on the boycott issue. Grant added that he could not believe the congressman "was afraid to come on" the program and that Rosenthal should lay aside his

11626 F.C.C. 2 d 583 (1970).

${ }^{117} \mathrm{Id}$. at 584 .

11842 F.C.C.2d 1106 (1973).

${ }^{119}$ Id. at $1108-09$.

120 51 F.C.C.2d 385 (1975), vacated and remanded, 530 F.2d 1001 (D.C. Cir. 1976). 
"prejudices" and discuss the "public issue."121 At approximately 12:45 P.M., a full two hours after these comments were made, Grant was discussing with a caller some vaguely suggested improprieties involving mothballed government ships. In response to the caller's spontaneous outburst of praise for Grant, Grant stated: "[W]hen I hear about guys like Ben Rosenthal ... I have to say I wish there were a thousand Bob Grants 'cause then you wouldn't have ... a coward like him in the United States Congress ...."."122

After Rosenthal filed a complaint, the Commission ruled that the "coward" comment was a personal attack, finding that the controversial issue of public importance was the nationwide meat boycott that Grant had discussed at 10:45 A.M. Most of those listening during the 12:45 lunch hour, when Rosenthal was called a coward, probably never heard the boycott issue discussed. For these listeners, the remark, thrown into an unrelated discussion of mothballed ships, must have made little sense. Those persons who did hear the earlier discussion doubtless would have realized that it was nothing more than Grant expressing frustration at Rosenthal's refusal to be interviewed. The Commission, however, supplying no further analysis, cited Manne and O'Brien to support its conclusion that the attack was made during the presentation of the boycott issue. ${ }^{123}$ Both cases are arguably inapposite, however, because, in each, the attacks were made in the context of continuing discussions of the issue in question.

The case was appealed to the Circuit Court for the District of Columbia, which reversed the Commission's decision. ${ }^{124}$ The court found that the station's arguments that Grant's remark did not occur during discussion of a controversial public issue "could hardly be called insubstantial," 125 and concluded that the Commission had "made its own judgment, instead of judging the objective reasonableness of the licensee's determination." ${ }^{126}$ That "[t]he Commission's decision amounted to a significant extension of the Personal Attack Rule to embrace instances where an alleged attack is separated by a substantial time lapse from the

\footnotetext{
${ }^{121} \mathrm{Jd}$. at 385.

122 Id.

$123 \mathrm{Jd}$. at 387.

12.4 Straus Communications, Inc. v. FCC, 530 F.2d 1001 (D.C. Cir. 1976).

$125 \mathrm{Id}$. at 1010 .

${ }^{126} \mathrm{Jd}$. at 1011 .
} 
issue discussion to which it supposedly relates" 127 was considered a further demonstration of the reasonableness and good faith of the station.

The Commission must reconsider its position in future cases. The court, in a footnote, pointed out that its opinion would not necessarily bar the Commission's interpretation once that interpretation is communicated to broadcasters. ${ }^{128}$ But when the relation of an attack to the underlying issue is as remote as it was in Straus, the policies underlying the attack rules-informing the public, providing access for the expression of views, and preventing stations from exercising undue political influence ${ }^{12.9}$-are not served by requiring the station to offer an opportunity to respond. In Straus the remarks simply had nothing to do with the issue being discussed-mothballed ships-and were exceedingly remote in time from the identified controversial issue of public importance, the meat boycott. ${ }^{130}$ The Commission's interpretation, at least as evidenced in Straus and Manne, seems so broad as to practically read the "during the presentation" requirement out of the attack rules.

\section{Other Problems}

Although the Commission has exempted bona fide newscasts, on-the-spot coverage of news events and news interviews, as well as news commentary or analysis contained in any of these formats, ${ }^{131}$ it has not exempted news documentaries or news commentary outside of the above contexts. If standard journalistic practices justify an exemption for other forms of news coverage, ${ }^{132}$ they likewise should justify an exemption for news documentaries. Broadcasters surely do not lose their journalistic standards when they move from one form of news coverage to another.

The Commission has indicated that, in providing an oppor-

${ }^{127} I d$.

${ }^{128}$ Id. n.28.

${ }^{129}$ See text accompanying notes 9-10 supra.

131) Even had the remarks borne a closer relationship to the controversial issue of public importance, in terms of the articulated purposes of the rules one must wonder what purpose would have been served by requiring an opportunity to respond. What additional public knowledge about the boycott would have been gained by hearing Congressman Rosenthal's reaction to being called a coward for not appearing on Bob Grant's phone-in show? See text accompanying notes $135-41$ infra.

131 See text accompanying notes 50-52 supra.

132 See note 51 supra \& accompanying text. 
tunity to respond to an attack, total time and frequency ratios and time of day comparisons must be closer than in the general fairness context. ${ }^{133}$ It has failed to go further, however, and define more precisely what constitutes a "comparative opportunity" for the attack victim.

Similarly, the Commission has not addressed the length of time a broadcaster may wait, after notifying the attack victim, before airing the response. In the political editorial situation, the election places a natural outer limit for responses, but no such easy answers exist in the personal attack context.

Finally, if a dispute erupts over whether a reply opportunity must be given, the Commission may take close to a year to rule on the matter-by which time the election may have been held or the attack forgotten. Of course, some administrative delay is inevitable, but the record indicates that the FCC has been lax in its administration of these disputes. ${ }^{134}$

\section{The Argument for Repeal of the Personal Attack Rules}

Although the Commission's enforcement of the personal attack rule deserves criticism, the real problem lies in the rule itself. The rule's failure to serve the policies underlying the fairness doctrine, the administrative complications the rule has spawned, its impingement on first amendment freedoms, and the availability of alternative relief support the conclusion that the rule should be repealed in toto.

The attack rule, as part of the fairness doctrine, is justifiable only to the extent it furthers that doctrine's policies. The attack rules do not fulfill the objectives of informing the public and providing alternative viewpoints with media access on important issues. Response opportunities are required only when the discussion ceases to focus on issues and turns to ad hominem argumentation. The rules do not apply if a specific ballot issue is endorsed or attacked, a major controversial issue in the community

${ }^{133}$ See note 80 supra \& accompanying text.

134 A study of all fairness cases considered during the first half of 1973 found an "average delay of about eight months between broadcast and ruling." The study also revealed a "number of cases in which several years elapsed." Geller, The Fairness Doctrine in Broadcasting, 37 \& app. D (Dec. 1973) (Rand R-1412F.F.). In Francis X. Bellotti, 10 F.C.C.2d 328 (1967), for example, the original complaint was made on Oct. 20, 1966, a few weeks prior to the November election; the Commission's ruling was delivered on Sept. 27, 1967. 
is discussed, or a critical piece of legislation is criticized. What great democratic public benefit comes from knowing that a reporter may not have used her legs to get stories or that a radio station's managers may not have defrauded an insurance company? To a large extent, the personal attack rules generate name calling exercises, allowing those parties whose personalities are criticized to rebut the charges without requiring rebuttal opportunities on the more substantive issues.

Nor do the attack rules deal directly with the problem of broadcasters' undue influence on important public issues. Response opportunities must be extended only when remarks focus on personal qualities rather than on the underlying issues. Personal attack exchanges, however, do not really address the important public questions. Moreover, rather than resulting from a station management's deliberate decision to influence the public, the cases suggest that personal attacks usually result from a caller's comments, an interviewee's remarks, or a talk show host's getting carried away on the air.

Although the personal attack and political editorial rules were held to be constitutional in Red Lion ${ }^{135}$ the failure of the personal attack rules to serve fairness doctrine policies suggests that the rules deserve reconsideration. Although the Red Lion Court suggested that the rules do impose restraints on broadcasters' exercise of their first amendment rights, it nonetheless determined:

Because of the scarcity of radio frequencies, the Government is permitted to put restraints on licensees in favor of others whose views should be expressed on this unique medium. . . . It is the right of the viewers and listeners, not the right of the broadcasters, which is paramount. ... It is the right of the public to receive suitable access to social, political, esthetic, moral, and other ideas and experiences which is crucial here. ${ }^{136}$

Now that it has become clear that the attack rules do not really provide an opportunity for spokesmen to address or for the public to be informed about important substantive public issues, Red Lion's justification for the attack rules' restraints on broadcasters' rights is called into question. 
Despite the FCC's declarations that the personal attack rules are only meant to inform further the public on important public issues, it is obvious that one of their key objectives is to protect the reputations of the individuals who are attacked. Given the burdens that the attack rules impose on broadcasters, such protection is poor justification for the rules, especially in light of the remedy for infringements of reputation provided by the law of defamation. Even were the personal attack rules to be justified in part as a defamation remedy, however, their provisions seem contrary to accepted principles of defamation law.

The personal attack rules stand the defamation standard on its head. As New York Times Co. v. Sullivan ${ }^{137}$ and its progeny have established, a higher liability standard protects newspapers when they attack a public figure ${ }^{\mathbf{1 3 8}}$ as opposed to a private person. ${ }^{139}$ In the personal attack situation, however, broadcast media burdens are precisely the opposite: an attack on a public figure, someone involved with an important public issue, triggers a heavier broadcaster burden. The broadcaster must follow rigorous notification procedures and has limited discretion in creating a reply opportunity. If a private figure, one not connected with a public issue, is attacked, however, the attack rules are not brought into play, and the broadcaster need not notify that person or broadcast any reply.

One might argue that insofar as Sullitan deprived public figures of a monetary damage remedy because their access to the media was, in effect, a sufficient alternative remedy, the personal attack rules serve to assure the effectiveness of that alternative remedy. A person involved in a controversial issue of public importance, however, is sufficiently assured of adequate media

${ }^{137} 376$ U.S. 254 (1964).

${ }^{138}$ A public official cannot recover damages "for a defamatory falsehood relating to his official conduct unless he proves that the statement was made with 'actual malice'-that is, with knowledge that it was false or with reckless disregard of whether it was false or not." Id. at 279-80. See also Time, Inc. v. Hill, 385 U.S. 374 (1967) (Sullivan standard applies to right of privacy action against magazine by private individuals involved in incident of public interest); Rosenblatt v. Baer, 383 U.S. 75 (1966) (criticism of former supervisor of county-owned ski resort); Garrison v. Louisiana, 379 U.S. 64 (1964) (criticism of state criminal court judges).

${ }^{139}$ Gertz v. Robert Welch, Inc., 418 U.S. 323 (1974):

$[P]$ rivate individuals are not only more vulnerable to injury than public officials and public figures; they are also more deserving of recovery. . . . [W] conclude that the States should retain substantial latitude in their efforts to enforce a legal remedy for defamatory falsehood injurious to the reputation of a private individual.

Id. at $345-46$. 
coverage without the imposition of added burdens on broadcasters. The rationales that private individuals do not have this same "self-help" opportunities, that they have not chosen voluntarily public exposure as have public officials and figures, ${ }^{140}$ and that the media needs to be able to cover public issues and officials without being inhibited seem as relevant to broadcasters and personal attacks as they do to newspapers and defamatory statements. ${ }^{141}$ The Commission has never explained these theoretical cross currents between the thrust of media burdens imposed under the personal attack rules and those imposed under defamation standards.

Ill-fitted to fulfill their purported goals, the personal attack rules also present large administrative difficulties for broadcasters. A personal attack may occur virtually any time someone speaks on the air. The licensee must decide whether an attack was made, whether there was a controversial public issue, and whether there was a sufficient nexus between the two. Once the licensee finds these three elements to exist, the victim(s) of the attack promptly must be notified and provided with a script, tape, or accurate summary. Finally, the licensee must decide what type of response opportunity is reasonable. Complex judgmental decisions must be made, with a possible fine or loss of license imposed if the FCC finds any of these decisions unreasonable. Such pressures well may inhibit the management and staff of stations from fully expressing their views and cause them to curtail the opportunities for broadcast expression offered the public.

In sum, the personal attack rules have not fulfilled fairness doctrine objectives, have generated severe administrative problems, and have raised constitutional concerns. For these reasons, they should be repealed.

\section{An Uneasy Case for Retention of Modified Political Editorial Rules}

The political editorial rules are distinguishable in terms of function, administration, and effect from the personal attack rules. The editorial rules do represent restraints on broadcasters' first amendment rights ${ }^{142}$ and do impose administrative burdens

\footnotetext{
140 See id. at 344-45.

${ }^{1+1}$ See New York Times v. Sullivan, 376 U.S. at 270-83.

${ }^{142}$ See Miami Herald Publishing Co. v. Tornillo, 418 U.S. 241 (1974) (a right of
} 
on broadcasters. On balance, however, they warrant retention.

In the political editorial situation the licensee not only condones the editorial, he uses his exclusive and powerful airwave frequency to explicitly advocate support of a candidate. There is no attempt to balance facts as in a typical news broadcast. Indeed, the licensee's objective is to bias the audience towards his point of view. A broadcast spokesman reflects the views of station management in a most direct way. The political editorial rules require that the broadcaster let his listeners hear other candidates with conflicting views. Thus, the political editorial obligations directly further the fairness doctrine goal of preventing powerful broadcasters from unfairly using their influence. The political editorial rules also further the other fairness doctrine objective of informing the public by granting access for spokesmen to discuss important public issues. Candidates are given the opportunity to address substantive campaign issues, ${ }^{143}$ and such political responses come at a critical time for democratic debate-immediately before an election.

Administratively, the political editorial rules, though not unburdensome, ${ }^{144}$ present fewer problems than the personal attack rules. The licensee does not have to determine whether a personal attack has occurred, what controversial issue of public importance has been raised, and whether that issue is so connected with the attack so as to have occurred during the attack. These difficult judgmental questions are simply not relevant to political editorials. The political editorial rules are triggered by a licensee's endorsement of a specific individual. ${ }^{145}$ Once this easily discernible event occurs, the rules come into operation.

reply for political candidates statutorily imposed by Florida on neuspapers inhibited newspaper journalists and violated the first amendment).

1*3 The need to supply every qualified candidate who was not favored in an editorial the right to reply, however, undoubtedly inhibits some broadcasters from airing political editorials. In the usual editorial or other fairness situation, only one or two reply spokesmen need be presented. In the political editorial situation, many more may be necessary, resulting in burdensome notification requirements and the offering of much free time.

${ }^{144}$ See note 147 infra \& accompanying text (reply obligations resulting from editorials on an issue closely associated with a candidate). Complications also may arise in determining when broadcast statements are the "official opinion" of the licensee and thus subject to the political editorial rules. That editorial-type statements by broadcast announcers are "made with the approval of the management of the station, does not necessarily mean that the statements were intended or represented on the air as the official opinion of the management of the station." Peter H. Beer, 48 F.C.C.2d 1067, 1068 (1974).

${ }^{145}$ Bul sep note 144 supra. 
Finally, it should be noted that the political editorial rules do parallel existing equal time requirements. ${ }^{146}$ As long as the latter are in effect, the political editorial rules seem a natural corollary. It would be inconsistent to require that broadcasters give candidates equal opportunities to appear on their stations, yet allow broadcasters to editorialize as much as they want in favor of or against a particular candidate. The personal attack rules, on the other hand, have no such connection with the statutory framework.

Although the political editorial rules should be maintained, some changes are desirable. The Commission could take much of the guesswork out of compliance with the rules by providing more precise guidelines on what constitutes a reasonable opportunity to respond. Reply parameters are tighter than in the traditional fairness setting, but they are still unnecessarily vague. The political editorial rules have also been greatly complicated by the FCC's invoking them whenever a station editorializes on an issue clearly identified with a particular candidate, even if the candidate is not directly opposed and the campaign is not

14647 U.S.C. $\$ 315$ (a) (Supp. V 1975). The equal time rule itself has been the deserving object of criticism. See, e.g., Derby, Section 315: Analysis and Proposal, 3 Harv. J. LEGIS. 257 (1965-66); Erbst, Equal Time for Candidates: Faimess or Frustration?, 34 So. CAL. L. Rev. 190 (1961). Although it is beyond the scope of this Article to explore the hotly debated equal time rule, 42 U.S.C. $\$ 315$ (1970 \& Supp. V 1975), equal time also should be subject to reevaluation. The inhibitory effect of the free time aspects of this rule may be even greater than the effects of the political editorial rule. An improved structure might eliminate equal time requirements for any program on which a candidate appears but does not pay for his broadcast as he does for political commercials. In light of the public's great need to hear issues discussed by candidates during campaign periods, the major party candidates, at least in the presidential elections to begin with (congressional elections could be phased in soon thereafter), might be given free backto-back periods of time to discuss the issues (perhaps one-half hour per candidate) each week for five or six weeks prior to an election. Minor qualified candidates might be given less time in accord with a prearranged formula based on previous vote tallies or petition. These broadcasts would be devoted to discussions of issues in detail and would be in addition to any presidential debates the networks might arrange (without any equal time requirements if the debates were aired without payment from the candidates). During these time periods the candidates could discuss or present the issues as they wished, without editorial interference. Such a scheme would fulfill the critical democratic need for extended discussion of important public issues during campaign periods and get away from the limited coverage of presidential issues inherent in short newscasts and broad-ranging presidential debates. It would also mitigate many of the inhibitory effects of the present equal time law and be simple to administer. Licensees would be free to cover any candidates they chose, in any format they desired, without having to give time to every other qualified political candidate. Unlike the political editorial situation, where broadcasters are consciously trying to bias the public towards their point of view about a candidate, the assumption would be that good journalistic practices would cause licensees to be fair in their candidate coverage. Equal time requirements still would prevail for paid political advertising, an arrangement that has a lesser inhibitory effect. 
mentioned. ${ }^{147}$ One need only consider the great number of important campaign issues with which candidates often can be identified to appreciate the administrative problems inherent in applying this obligation. Such an obligation too often could result in inhibiting broadcasters who want to speak out on the issues. This interpretation also seems inconsistent with the FCC's failure to impose any reply requirements for editorials on ballot issues.

\section{Conclusion}

The personal attack and political editorial rules have historically been wedded, but the time has come to sunder the union. Although both were intended to serve the policies of the fairness doctrine, only the political editorial rules have furthered those goals. The failure of the personal attack rules is compounded by the burdens they impose on broadcasters both administratively and in the exercise of first amendment rights.

The long run solution to the problems raised by the personal attack and political editorial rules lies in expanding the number of electronic communications outlets available to the American people. The federal government must do more to promote cable, UHF, and public television as well as other means in order to increase the diversity of media access and public issue debate available to the American people. With such an abundance of communication opportunity, candidates, attack victims, and other parties will have little difficulty in finding opportunities to reply to political editorials or personal attacks. Because frequency scarcity will be an outdated rationale, no need nor justification for burdening licensees with the political editorial or personal attack rules will then exist.

In the short run, however, only the personal attack rules should be eliminated. Maintenance of such response opportunities is counterproductive and inimical to the public interest. The FCC can repeal the rules on its own initiative. Congress can, of course, eliminate them by statute.

Until creation of a communications system of abundance, there is greater justification for maintaining the political editorial

${ }^{147}$ See Taft Broadcasting Co., [1975] 33 RaD. REg. 2d (P \& F) 1260. Even when a candidate is not opposed expressly or the election directly referred to, "a licensee editorial gives rise to the affirmative obligations of the political editorial rule if it takes a partisan position on a politically significant issue which is readily and clearly identified with a legally qualified candidate." Id. at 1268. 
rules. If these rules are to be retained, however, the Commission should reverse its decision to impose political editorial obligations whenever a broadcaster editorializes on an issue related to a campaign because the ruling is difficult to administer, almost impossible to decipher intelligently, and is especially inhibiting to licensees. In addition, the parameters for reply obligations in political editorials should be given further definition. ${ }^{148}$ Both broadcasters and candidates should know their rights.

${ }^{148}$ Thus, candidates responding to a licensee's editorial endorsement of an opponent should be entitled to a similar time period for reply. A 6:00 P.M. licensee editorial on a Tuesday night should require a reply between 5:00 and 7:00 P.M. on a similar week night. At the least, a prime-time editorial should require prime-time responses. Candidates should be offered at least roughly equal total time to reply to licensee editorials. Further, frequency of broadcast must be given adequate attention. If a licensee's political editorials are twice as frequent as a candidate's reply, the allocation formula should be considered inherently suspect; the licensee should be asked to justify the 2 to 1 frequency ratio with a demonstration that the total time ratio largely offsets the frequency differential. 